\title{
Morphological aspects and effect of carbon sources in the physiology of Fusarium oxysporum f. sp. passiflorae
}

\author{
Aricléia de Moraes Catarino', Antonia Alice Costa Rodrigues², Leilson Lopes Santos Silva², \\ Leonardo de Jesus Machado Gois de Oliveira², Diogo Herison Silva Sardinha², Marlon Gomes da Costa²
}

${ }^{1}$ Post-Graduation Program in Agriculture in the Humid Tropics, National Research Institute of the Amazon, Manaus, AM, Brazil, ${ }^{2}$ Post-graduation Program in Agroecology, State University of Maranhão, São Luís, Maranhão State, Brazil

\section{A B S TR A C T}

\begin{abstract}
The objective of this study was to evaluate the morphological and physiological characteristics of $F$. oxysporum f. sp. passiflorae. Isolates were obtained from yellow passion fruit plants with fusariosis symptoms grown in four production poles. The pathogenicity test was carried out on seedlings of this crop, under greenhouse conditions. The morphological characters evaluated were the size of macroconidia and microconidia in single conidiophores or in false heads; number of septa, presence of basal cell in the macroconidia and chlamydospores, and the aspects of the colonies of the isolates cultivated in potato dextrose agar (PDA) culture medium for aerial mycelium formation and colony coloration. The carbon sources: starch, lactose, maltose and sucrose were tested for the three most virulent isolates obtained in the pathogenicity test. The mycelial growth was obtained through readings every 24 hours of the diameter of the colony in two diametrically opposite directions. Sporulation determination was performed by counting spores in a Neubauer chamber. The isolate Fusarium oxysporum f. sp. passiflorae 4 (FOP 4) was the most virulent. There was variation in the morphological characteristics of all the isolates. The starch provided the highest mycelial growth and the isolates showed preferences for a particular carbon source in the sporulation test.
\end{abstract}

Keywords: Fusariosis; Morphology; Mycelial growth; Sporulation; Yellow passion fruit

\section{INTRODUCTION}

The passion fruit belongs to the genus Passiflora, containing 15 cultivated and 12 commercialized species, being the Passiflora edulis Sims f. flavicarpa Deg. (Yellow passion fruit) the most important (Yockteng et al., 2011). The Fusarium wilt, whose etiological agent is the fungus Fusarium oxysporum f. sp. passiflorae is a important disease for this culture because it causes great damage due to plant death (Fischer and Rezende, 2016).

The Fusarium taxonomy is quite complex and has undergone several changes since the first descriptions made by Link in 1803 (Tapia and Amaro, 2014). Their identification remains an important task for the diagnosis of many plants in the laboratory, because as a genus, Fusarium lacks a large number of morphological characters that can be used to easily differentiate species. This problem has led to numerous definitions of less welldefined species and has made it difficult to identify the actual species, resulting in debates between individuals with very different views of what could be a species (Leslie and Summerell, 2006).

The F. oxysporum species is without a doubt the most economically important in the Fusarium genus given its numerous hosts and the level of loss that can result when it infects a plant. Exhibits high degree of variability in the morphological and physiological characteristics, being considered the most widely disseminated Fusarium species that can be recovered from most soils (Leslie and Summerell, 2006), varying significantly with the environmental conditions (Kumara and Rawal, 2008) and occupying diverse ecological niches and geographic regions (Islam, 2015). Thus, different substrates can allow their growth (Godswill et al., 2015; Chougule and Andoji, 2016; Shinde and Hallale, 2016; Thaware et al., 2016; Nath et al., 2017), among them, Potatro-Dextrose-Agar, Agar Sabouraud, Carnation-Agar, Spezieller Nährstoffarmer Agar (Tapia and Amaro, 2014), glucose (dextrose), D-fructose, D-manose, D-galactose, starch, D-xylose, D-sorbose, D-mannitol, sucrose, D-lactose, D-maltose,

\footnotetext{
*Corresponding author:

Aricléia de Moraes Catarino, Post-Graduation Program in Agriculture in the Humid Tropics, National Research Institute of the Amazon, Manaus, AM, Brazil. E-mail: amoraescatarino@gmail.com
}

Received: 06 August 2017; Accepted: 07 January 2017 
citric acid, succinic acid, tartaric acid, D-raffinose, tannic acid, melibiose and dextrin (Shilpa et al., 2015).

Fusarium species may be differentiated based on the size and shape of macroconidia, presence and absence of microconidia and chlamydospores, colony morphology (Albores et al., 2014), mycelial growth and sporulation on different substrates (Godswill et al., 2015; Shilpa et al., 2015; Chougule and Andoji, 2016; Shinde and Hallale, 2016; Thaware et al., 2016; Nath et al., 2017).

Nowadays, there is a tendency to ignore the morphological characters of the fungi, which may make it impossible to identify species correctly, since the absence of identification of colonies by means of morphological characterization prevents the subsequent construction of molecular databases of these organisms (Lazarotto, 2013). Despite advances in molecular taxonomy, the classical taxonomy remains valid (Tapia and Amaro, 2014).

According to our knowledge, this is the first morphophysiological characterization of the F. oxysporum species in the form specialis passifforae. Therefore, the objective of this paper was to evaluate the morphological characteristics and the effect of carbon sources on the mycelial growth and sporulation of F. oxysporum f. sp. passiflorae.

\section{MATERIAL AND METHODS}

\section{Identifying isolates of F. oxysporum f. sp. passiflorae}

Isolates were obtained from passion fruit plants cultivated at the production sites of the Cinturão Verde (FOP 1 and FOP 2), Quebra Pote (FOP 3), Panaquatira (FOP 4) and Sítio Bom Jesus/Cidade Olímpica (FOP 5), all presenting characteristic symptoms of Fusarium wilt.

The plants were collected and taken to the Phytopathology Laboratory at the Nucleus of Agronomic Biotechnology - NBA at the State University of Maranhão - UEMA for further analysis. Fragments of the intermediate part of the lesions of the plant colon were removed and submitted to desinfection with alcohol $50 \%$, hypochlorite solution 1:3 and sterilized distilled water (SDW) and later transferred to the potato-dextrose-agar (PDA) culture medium.

The identification of the isolates was done according to the morphological aspects and with the aid of microcultures (Menezes and Assis, 2004). This technique consisted of the inoculation of a small block of agar $\left(1 \mathrm{~cm}^{2}\right)$ with mycelial fragment of the fungus placed on the upper edge of each side of block and covered with a coverslip. Microcultures were prepared in triplicate and coverslips were putted on supports inside Petri dish containing moistened filter paper.
Incubation was performed under temperature of $25 \pm 2$ ${ }^{\circ} \mathrm{C}$, for a period of 7 days and photoperiod of 12 hours (Sousa et al., 2008). The coverslips were removed, placed on slides containing Amann's blue dye and examined under the optical microscope for visualization of the formed structures.

\section{Pathogenicity test}

The pathogenicity test was carried out in a greenhouse at the Agronomic Biotechnology Nucleus of the State University of Maranhão - UEMA. For this, yellow passion fruit seeds were grown in plastic pots with a capacity of $3.0 \mathrm{~kg}$, containing autoclaved soil and keeping two plants/ pot.

For the preparation of the inoculum, isolates were cultivated in Petri dishes containing PDA for 7 days. After that, $20 \mathrm{~mL}$ of SDW were added to each plate and scraped from the colonies with glass slides, and the inoculum was adjusted to $10^{6}$ conidia/mL with the aid of a Neubauer chamber.

The inoculation was performed when the plants reached $20 \mathrm{~cm}$ in height or approximately 50 days of age, through the wounding method on one side of the root system (Alfenas and Ferreira, 2007), with $20 \mathrm{~mL}$ of the suspension per plant. The controls were inoculated following the same procedure, using only SDW.

The evaluation was performed 20 days after inoculation, using the scale of notes of according to Cia et al. (1977), with modifications, where note $1=$ healthy plants; note $2=$ plants with internal darkening only in the basal part of the roots and $35 \%$ of the yellow leaves; note $3=$ plants with browning above the basal part of the roots and $75 \%$ of yellowish leaves and note $4=$ dead plants.

The experiment was carried out in a randomized complete block design with five treatments corresponding to the 5 isolates and five replicates ( 5 isolates $\times 5$ replicates). The experimental unit was a pot containing two plants. Statistical analyzes were performed by the statistical program Assistat 6.2 (Silva and Azevedo, 2002) and the means compared by the Tukey test at $5 \%$ probability.

\section{Morphological characterization}

The evaluation of the morphological characteristics was performed according to Menezes and Assis (2004) to verify size of macroconidia and microconidia in simple conidiophores or false heads; number of septa and the presence of basal cell in the macroconidia and chlamydospores and through the characteristics of the colonies of the fungus cultured in PDA such as aerial mycelium formation and colony coloration. For each 
isolate, the length and width of 50 macroconidia and 50 microconidia were measured, establishing a mean.

\section{Physiological characterization}

The effect of different carbon sources was tested on mycelial growth and sporulation of the isolates. For this purpose, the carbon sources lactose, maltose, starch and sucrose were used in the amount of $10 \mathrm{~g}$, having as the basal medium that of Lilly and Barnett (1951) and as a control the synthetic PDA nutrient medium.

Only the three most virulent isolates in the pathogenicity test were selected for evaluation in this test, thus culture discs with approximately $5 \mathrm{~mm}$ diameter were deposited in the center of the plate containing each carbon source.

The evaluation of the mycelial growth was done by means of readings of the diameter of the colony in two diametrically opposed directions every 24 hours, with the aid of a millimeter rule, defining an average for each repetition. The readings were completed on the $7^{\circ}$ day when colony completely covered the plaque diameter in one of the treatments.

The determination of sporulation was carried out by preparing a macroconidia suspension of each Petri dish, containing the different carbon sources and the evaluation occurred on the $7^{\circ}$ day of growth. To prepare the suspension, $20 \mathrm{~mL}$ of SDW was added to each Petri dish to remove the colony using the glass slide. After removal, the material was filtered through a double layer of sterile gauze and the concentration $\left(\times .10^{5}\right.$ conidia $\left./ \mathrm{mL}\right)$ determined through the Neubauer chamber to obtain a mean of two readings for each replicate of the treatments.

The statistical design was completely randomized in a factorial arrangement $3 \times 5$ (3 isolates $\times 5$ carbon sources) in a total of 15 treatments with four replicates each. Statistical analyzes were performed by the statistical program Statistica ${ }^{\circledR} 6.0$ (Kuypers, 2001) and the means compared by the Tukey test at $5 \%$ probability.

\section{RESULTS}

The pathogenicity of all isolates was confirmed, but there was no significant difference between them (Fig. 1), although isolate FOP 4 caused besides yellowing and darkening of the vessels, death in some inoculated plants, being therefore the most virulent.

The diameter of the macroconidia in isolates ranged from 18.22 to $30.56 \mu \mathrm{m} \times 3.06$ to $3.92 \mu \mathrm{m}$. According to length/ width $(\mathrm{L} / \mathrm{W})$ ratio, isolates FOP 2 and FOP 5 showed longer and thinner macroconidia (9.34 and 8.41), respectively and

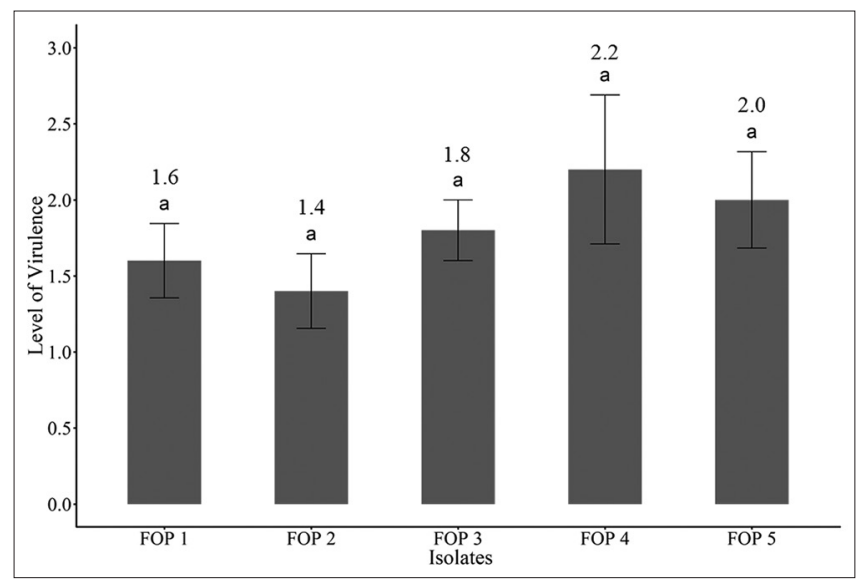

Fig 1. Pathogenicity test and selection of the isolates of $F$. oxysporum f. sp. passiflorae for virulence in yellow passion fruit plants. In each series, mean values labeled with the same alphabetical letter are not significantly different (at $p<0.05)$ according to Tukey. The standard deviation for isolates were: FOP 1 and FOP 2 - 0.5477226; FOP 3 0.4472136 ; FOP $4-1.0954451$ and FOP $5-0.7071068$.

isolates FOP 1 and FOP 4 presented shorter and wider macroconidia (6.40 and 5.22), respectively (Table 1). Regarding microconidia, the diameter ranged from 5.35 to $8.75 \mu \mathrm{m} \times 2.32$ to $3.25 \mu \mathrm{m}$. The isolate FOP 2 showed a greater L/W ratio (2.85), followed by isolates FOP 1 (2.30), FOP 3 (2.28), FOP 4 (2.08) and FOP 5 (2.06) (Table 1). The number of septa in the macroconidia ranged from 2 to 5 for isolates FOP 1 and FOP 4, from 3 to 6 for isolates FOP 2 and FOP 3 and from 3 to 5 for isolate FOP 5.

There was variation in colony coloration of the isolates in PDA medium. The white coloration was observed in isolates FOP 1 and FOP 4 , the salmon coloration in isolates FOP 2 and FOP 5 and the pale rosy coloration in isolate FOP 3. Isolates FOP 2, FOP 3 and FOP 5 formed aerial mycelium and isolates FOP 1 and FOP 4 formed mycelium cotonous. The presence of simple conidiophores and basal cell were observed in all isolates. The presence of chlamydospores was not observed in isolates FOP 2 and FOP 3 and only the FOP 4 and FOP 5 isolates presented false head formation (Table 2).

The three most virulent isolates (FOP 3, FOP 4 and FOP 5), selected in the pathogenicity test were utilized to evaluate substrates in the physiology of F. oxysporum f. sp. passiflorae. The results showed that, among the carbon sources, the starch was the one that provided greater mycelial growth in the three evaluated isolates, although the treatments did not differ significantly for isolate FOP 5. Maltose was considered the second best substrate for isolates FOP 3 and FOP 5. However, for isolate FOP 4, the synthetic PDA medium was considered better after starch (Fig. 2).

In the study of sporulation, the three isolates evaluated showed preferences for a particular carbon source. 
According to the results, isolate FOP 3 obtained a better sporulation in medium containing starch, followed by sucrose, lactose, synthetic PDA and maltose. The isolate FOP 4 used better lactose, and then synthetic PDA, sucrose, starch and maltose. The isolate FOP 5 was best reproduced in medium containing maltose, followed by lactose, sucrose, synthetic PDA and starch (Fig. 3).

The Table 3 shows the mean of mycelial growth and sporulation of the isolates and standard deviation in each treatment.

\section{DISCUSSION}

F. oxysporum is responsible for a vast number of plant diseases, usually involving vascular wilt (Leslie and Summerell, 2006). In new plants, the leaves are pale green in color and a slight wilting of the new branches is observed, followed by lower leaf fall, general wilting and rapid plant death. In adult plants the disease causes yellowing of the new leaves, followed by wilt and death of the plant (Fischer and Rezende, 2016).

The isolates that cause this disease, most of the time, are specific, infecting only a small number of plant hosts and are differentiated based on pathogenicity as formae speciales. The subdivision of this species into formations has important implications for the diagnosis of the disease and control measures such as quarantine (Leslie and Summerell, 2006) aiming to prevent its spread to other places where does not occur.
The tropical race 4 (TR4) of F. oxysporum f. sp. cubense, for example, was described in the early 1990s in South Asia, and does not present in Brazil. Actually, this race is considered to be the grestest threat to world banana farming, as it is estimated that more than $80 \%$ of planted bananas are susceptible to this race. Thus, the monitoring of the occurrence and/or introduction of this race in Brazil is very important for the sustainability of the culture, being necessary to have laboratories capable of performing the diagnosis of the different pathogens of economic and quarantine importance (Andrade et al., 2013).

Diverse formae speciales of F. oxysporum have been described, similar as F. oxysporum f. sp. ciceri on chickpea (Thaware et al., 2016; Nath et al., 2017; Farooq et al., 2005; Khilare and Ahmed, 2011), F. oxysporum f. sp. lentis on lentil (Altaf et al., 2014), F. oxysporum f. sp. psidii on guava (Gupta et al., 2010; Hussain et al., 2012), F. oxysporum. f. sp. cubense on banana (Somu et al., 2014), F. oxysporum f. sp. zingiberi on ginger (Gupta et al., 2014).

It was observed variation in the diameter of macroconidia and microconidia, number of septa, presence of basal cell in the macroconidia and chlamydospores and characteristics of the colonies of the isolates studied.

Species within the genus Fusarium were characterized primarily on the basis of morphological characters as such the shape and size of macroconidia, microconidia and chlamydospores; the cells from which they originated,

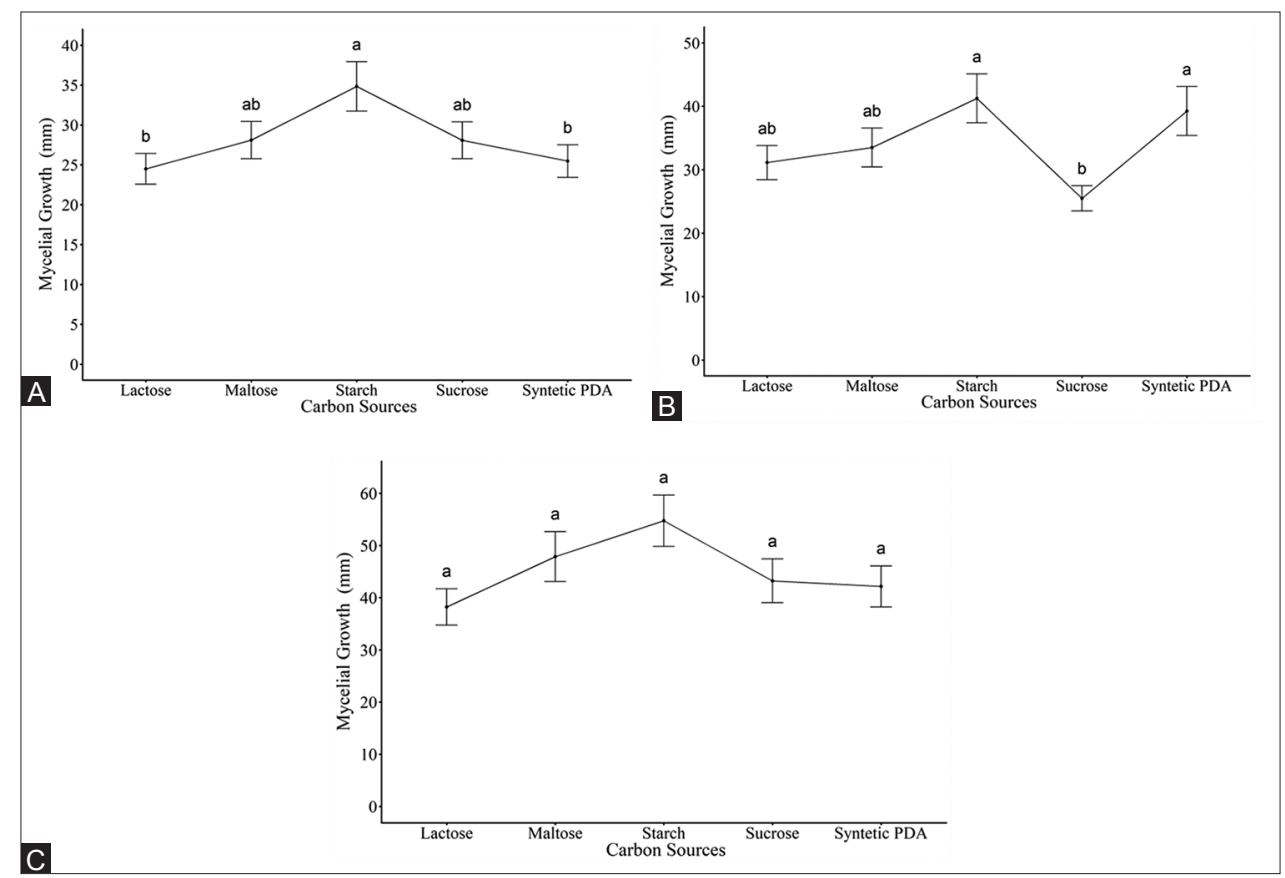

Fig 2. Influence of carbon sources on mycelial growth (mm) of the isolates of F. oxysporum f. sp. passiflorae. A) FOP 3; B) FOP 4; C) FOP 5. In each series, mean values labeled with the same alphabetical letter are not significantly different $($ at $p<0.05)$ according to Tukey. 


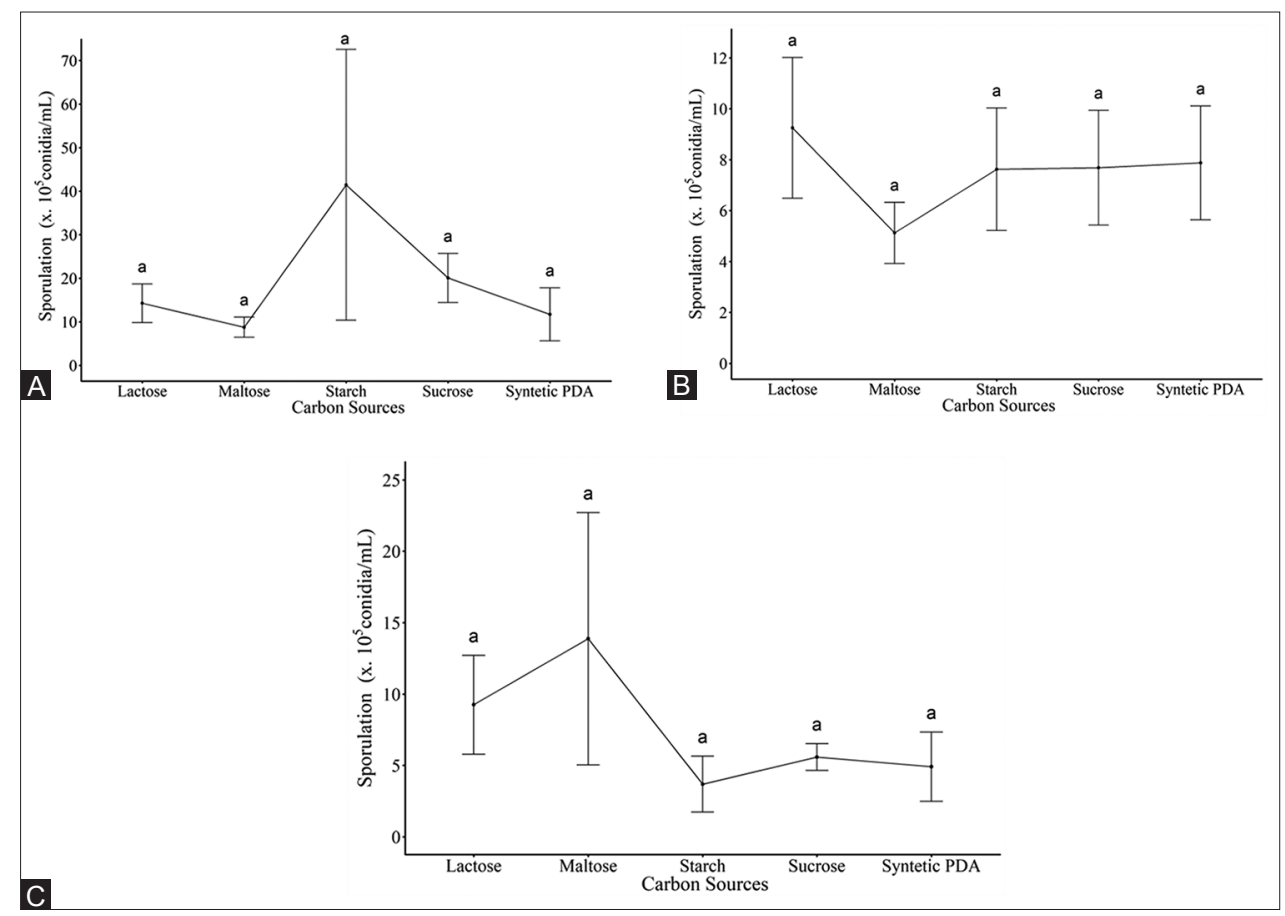

Fig 3. Influence of carbon sources on the production of macroconidia of the isolates of F. oxysporum f. sp. passiflorae. A) FOP 3; B) FOP 4; C) FOP 5. In each series, mean values labeled with the same alphabetical letter are not significantly different $($ at $p<0.05)$ according to Tukey.

Table 1: Test of the mean of the length, width and length/width (L/W) ratio of 50 macroconidia and 50 microconidia and the number of macroconidia septa of five isolates of $F$. oxysporum f. sp. passiflorae grown in PDA medium

\begin{tabular}{|c|c|c|c|c|c|c|c|}
\hline \multirow[b]{2}{*}{ Isolates } & \multicolumn{4}{|c|}{ Macroconidia } & \multicolumn{3}{|c|}{ Microconidia } \\
\hline & $\begin{array}{l}\text { Length }^{1}(\mu \mathrm{m}) \\
\text { Amplitude }\end{array}$ & $\begin{array}{l}\text { Width }^{1}(\mu \mathrm{m}) \\
\text { amplitude }\end{array}$ & Ratio $^{2}$ L/W & $\begin{array}{l}\text { Length }^{1}(\mu \mathrm{m}) \\
\text { amplitude }\end{array}$ & $\begin{array}{l}\text { Width }^{1}(\mu \mathrm{m}) \\
\text { amplitude }\end{array}$ & Ratio ${ }^{2}$ L/W & Conidia \\
\hline FOP 1 & $19.61(13.20-39.60)$ & $3.06(2.64-3.30)$ & 6.40 & $5.35(3.63-6.60)$ & $2.32(0.99-3.63)$ & 2.30 & \\
\hline FOP 2 & $30.56(19.80-46.20)$ & $3.27(2.97-3.63)$ & 9.34 & $8.75(3.63-10.23)$ & $3.07(2.64-3.63)$ & 2.85 & \\
\hline FOP 3 & $27.80(14.85-56.10)$ & $3.92(2.64-6.60)$ & 7.09 & $5.36(3.30-6.93)$ & $2.35(0.99-3.30)$ & 2.28 & \\
\hline FOP 4 & $18.22(12.87-39.60)$ & $3.49(2.64-7.59)$ & 5.22 & $6.77(3.30-11.55)$ & $3.25(2.64-3.96)$ & 2.08 & \\
\hline FOP 5 & $27.60(13.20-39.60)$ & $3.28(2.64-3.63)$ & 8.41 & $6.52(3.30-10.56)$ & $3.20(2.64-3.30)$ & 2.03 & \\
\hline
\end{tabular}

${ }^{1}$ Mean of $\mathbf{5 0}$ macroconidia and $\mathbf{5 0}$ microconidia for each isolate. ${ }^{2} \mathrm{~L} / \mathrm{W}=$ =lenght/width.

with secondary characters including pigments and other produced metabolites, growth rate and morphology of the colonies (Leslie and Summerell, 2011).
F. oxysporum presents significant variations between isolates such as colony colour, colony size, dry mycelial weight $(\mathrm{mg})$, size of microconidia, macroconidia 
Table 2: Aspects of the colonies and structures observed in the isolates of $F$. oxysporum $\mathrm{f}$. sp. passiflorae

\begin{tabular}{|c|c|c|c|c|c|}
\hline Isolates & $\begin{array}{c}\text { Mycelial } \\
\text { characteristics }\end{array}$ & $\begin{array}{c}\text { Simple conidiophores } \\
\text { and basal cell }\end{array}$ & $\begin{array}{c}\text { Formation of } \\
\text { Chlamydospores }\end{array}$ & $\begin{array}{l}\text { Formation of } \\
\text { false heads }\end{array}$ & $\begin{array}{l}\text { Colonies } \\
\text { coloration }\end{array}$ \\
\hline FOP 1 & cotonous & present & present & absent & \\
\hline FOP 2 & aerial & present & absent & absent & \\
\hline FOP 3 & aerial & present & absent & absent & \\
\hline FOP 4 & cotonous & present & present & present & \\
\hline FOP 5 & aerial & present & present & present & \\
\hline
\end{tabular}

Table 3: Mean of mycelial growth and sporulation of the isolates of $F$. oxysporum $\mathrm{f}$. sp. passiflorae and standard deviation in each treatment

\begin{tabular}{|c|c|c|c|c|c|c|}
\hline Isolates & FOP 3 & FOP 3 & FOP 4 & FOP 4 & FOP 5 & FOP 5 \\
\hline $\begin{array}{l}\text { Carbon } \\
\text { sources }\end{array}$ & $\begin{array}{c}\text { Mycelial } \\
\text { growth }(\mathrm{mm})\end{array}$ & $\begin{array}{l}\text { Standard } \\
\text { deviation }\end{array}$ & $\begin{array}{c}\text { Mycelial } \\
\text { growth }(\mathrm{mm})\end{array}$ & $\begin{array}{l}\text { Standard } \\
\text { deviation }\end{array}$ & Mycelial growth (mm) & $\begin{array}{l}\text { Standard } \\
\text { deviation }\end{array}$ \\
\hline Lactose & 24.5 & 10.19168 & 31.1 & 14.26 & 38.2 & 18.36335 \\
\hline Maltose & 28.1 & 12.31106 & 33.5 & 16.29 & 47.8 & 25.22992 \\
\hline Starch & 34.8 & 16.37187 & 41.2 & 20.37 & 54.7 & 26.06029 \\
\hline Sucrose & 28.0 & 12.24874 & 25.5 & 10.51 & 43.2 & 22.14326 \\
\hline Syntetic PDA & 25.4 & 10.79088 & 39.2 & 20.37 & 42.1 & 20.78731 \\
\hline $\begin{array}{l}\text { Carbon } \\
\text { sources }\end{array}$ & $\begin{array}{c}\text { Sporulation } \\
\text { (x. } 105 \text { conidia/mL) }\end{array}$ & $\begin{array}{l}\text { Standard } \\
\text { deviation }\end{array}$ & $\begin{array}{c}\text { Sporulation } \\
\text { (x. } 10^{5} \text { conidia/mL) }\end{array}$ & $\begin{array}{l}\text { Standard } \\
\text { deviation }\end{array}$ & $\begin{array}{c}\text { Sporulation } \\
\text { (x. } 10^{5} \text { conidia/mL) }\end{array}$ & $\begin{array}{l}\text { Standard } \\
\text { deviation }\end{array}$ \\
\hline Lactose & 14.25 & 8.867074 & 9.25 & 5.526452 & 9.25 & 6.913152 \\
\hline Maltose & 8.75 & 4.641300 & 5.12 & 2.402256 & 13.87 & 17.668828 \\
\hline Starch & 41.43 & 62.183993 & 7.61 & 4.815340 & 3.68 & 3.923089 \\
\hline Sucrose & 20.06 & 11.275665 & 7.69 & 4.506361 & 5.58 & 1.626602 \\
\hline Syntetic PDA & 11.69 & 12.200367 & 7.87 & 4.465143 & 4.92 & 4.849112 \\
\hline
\end{tabular}

and septations (Chougule and Andoji, 2016), colony coloration (Nath et al., 2017), mycelial types, presence of chlamydospores, apical and basal cells among other characteristics (Gupta et al., 2014; Hafizi et al., 2013; Lazarotto et al., 2014).

The morphology of the F. oxysporum colony in PDA varies greatly. The mycelium may be flaky, sparse or abundant and the coloration varies from white to pale violet. In some isolates the appearance of the staining may vary from yellow to orange when grown in PDA (Leslie and Summerell, 2006).

The formation of chlamydospores varies widely and is a taxonomic criterion that should be used with care, because when present is a fully useful criterion, but when absent, it should be evaluated along with other characteristics, since it can vary from one isolate to another or with successive repetitions of the same species (Burgess et al., 1994).

In the test of the variability of the isolates in the carbon sources, the three isolates evaluated showed a higher mycelial growth in starch, followed by maltose, for FOP 3 and FOP 5 isolates. According to Cochrane (1958), a good development of the fungus in starch is accompanied by a good growth of the same in maltose. This is due to the fact that maltose naturally occurs as a product of starch hydrolysis. The author states that starch is a better source 
of carbon than other simpler sources, such as glucose, because it is a compound that hydrolyzes slowly, giving the medium less accumulation of acids than this. In addition, polysaccharides and oligosaccharides are more efficient for fruiting fungi, than simple sugars.

The maltose and starch showed significantly highest growth of F. oxysporum f. sp. carthami among the sources tested followed by glucose, fructose, sucrose and manitol (Shinde and Hallale, 2016).

Although the isolates showed a relatively low growth rate, as observed in the results, there was good sporulation in some carbon sources. According to Dhingra and Sinclair (1995) the concentration of its constituents determines the quality and quantity of growth and whether sporulation or growth will dominate. A good culture medium can provide high sporulation and low mycelial growth.

Contrary to what has been mentioned above, it may also occur, so the minimum nutrient concentration required for mycelial growth is often not sufficient to produce spores, that is, generally the optimum nutritional condition for mycelial growth is not the better for spore production and often inhibits reproduction (Veras et al., 1997).

The isolates are able to use different carbon sources and demonstrate considerable variations in the efficiency of their growth. Among seven carbon sources tested, sucrose was the best one used by all F. oxysporum f. sp. cubense (Somu et al., 2014). Testing eight carbon sources on the physiology of soil fungi, among them F. oxysporum, a better performance was observed in maltose, glucose, lactose and sucrose (Islam et al., 2015).

Fungi easily colonize organic substances in the soil. The increase in inoculum potential and the severity of the disease is possibly correlated with the organic substances in the food. Cultured remains serving as food can also serve as a source of infection. The fungi become active first near to the soil surface and the fungal hyphae penetrates into the roots, causing a severe blockage in the xylem vessels, resulting in vascular wilt of the plants (Farooq et al., 2005).

The evaluation of a large number of structures, such as the size of macroconidia and microconidia in single conidiophores or false heads, number of septa, presence of basal cell in macroconidia, formation of chlamydospores, aerial mycelium formation and colony coloration is made to confirm the species of Fusarium, due to the great genetic variability to which it possesses. Besides these characteristics, we can study the behavior of the isolates in different substrates and thus verify their growth rates and sporulation.
According to Khilare and Ahmed (2011), fungal growth is totally absent in the absence of carbon sources. Carbon is the major structural component of fungal cells required for their growth and development.

\section{CONCLUSIONS}

The isolate FOP 4 of F. oxysporum f. sp. passiflorae was the most virulent. There was variation in the morphological characteristics of all the isolates. For physiology, starch provided the highest mycelial growth and the isolates showed preferences for a particular carbon source in the sporulation test.

\section{ACKNOWLEDGEMENTS}

The authors would like to thank to the "National Counsel of Technological and Scientific Development" (CNPq) by research funding.

\section{AUTHORS' CONTRIBUTIONS}

The experiment was conducted by Aricléia de Moraes Catarino with the collaboration of the authors Leilson Lopes Santos Silva, who was always present in the accomplishment of all the tests, Antonia Alice Costa Rodrigues, whose orientation was indispensable, Leonardo de Jesus Machado Gois de Oliveira and Diogo Herison Silva Sardinha who were present at some moments in the conduction of the experiments and of the author Marlon Gomes da Costa who carried out all the statistical analyzes.

\section{REFERENCES}

Albores, L. C., S. B. Baños, J. M. Herrera, L. B. Necha, M. H. López and A.C. Hernández. 2014. Morphological and molecular characterization of pathogenic isolates of Fusarium spp. obtained from gladiolus corms and their sensitivity to Jatropha curcas L. oil. Afr. J. Microbiol. Res. 8: 724-733.

Andrade, J. N. B., S. N. Costa, S. A. S. Oliveira, E. P. Amorim and F. Haddad. 2013. Implementação de Diagnóstico por PCR Para Fusarium oxysporum f. sp. Cubense (raça 4). (Abstr.).

Alfenas, A. C. and F. A. Ferreira. 2007. Inoculação de fungos fitopatogênicos. In: Alfenas, A. C. and R. G. Mafia, editors. Métodos em Fitopatologia, UFV, M.G., Viçosa, pp. 117-137.

Altaf, R., C. A. Rauf, F. Naz and G. Shabbir. 2014. Surveillance and morphological characterization of Fusarium isolates associated with lentil wilt. Pak. J. Phytopathol. 26: 85-90.

Andrade, J. N. B., S. N. Costa, S. A. S. Oliveira, E. P. Amorim and F. Haddad. 2013. Implementação de Diagnóstico por PCR Para Fusarium oxysporum f. sp. Cubense (raça 4).(Abstr.).

Burgess, L. W., B. A. Summerell, S. Bullock, K. P. Gott and D. Backhouse. 1994. Laboratory

Manual for Fusarium Research. 3rd ed. University of Sidney., Sydney, Australia. 
Chougule, P. M. and Y. S. Andoji. 2016. Studies on cultural and morphological variation among 20 isolates of Fusarium oxysporum causing wilt of tomato. Int. J. Dev. Res. 6: 7034-7037.

Cia, E., L. L. Gripp-Papp, J. Soave and C. A. M. Ferraz. 1977. Resistência de novos cultivares de algodoeiro a Fusarium oxysporum f. sp. vasinfectum e a Xanthomonas malvacearum. Summa Phytopathol. 3: 260-270.

Cochrane, V. W. 1958. Physiology of Fungi. John Wiley \& Sons Inc., New York, U.S.

Dhingra, O. D. and J. B. Sinclair. 1995. Basic Plant Pathology Methods. $2^{\text {nd }}$ ed. Lewis Publishers., Boca Raton, FL.

Farooq, S., S. H. M. lqbal and C. H. A. Rauf. 2005. Physiological studies of Fusarium oxysporum f. sp. ciceri. Int. J. Agric. Biol. 7: $275-277$.

Fischer, I. H. and J. A. M. Rezende. 2016. Doenças do maracujazeiro. In: Amorim, L., J. A. M. Rezende, A. Bergamin Filho and L. E. A. Camargo, (Eds.), Manual de Fitopatologia: Doenças de Plantas cultivadas, Agronomica Ceres, M.G., São Paulo, pp. 535-543.

Godswill, N. N., E. N. Toussaint, Madi-Galdima, N. M. Armand, N. E. G. Frank, K. T. Samuel, M. M. Emmanuel and D. Didier. 2015. Isolation and in vitro characterization of Fusarium oxysporum f. sp. elaeidis, causal agent of oil palm (Elaeis guineensis Jacq.) vascular wilt. Res. Plant Sci. 3: 18-26.

Gupta, M., K. Jarial and A. Vikram. 2014. Morphological, cultural, pathological and molecular variability among Fusarium oxysporum f.sp. zingiberi isolates. Int. J. Bioresour. Stress Manag. 5: 375-380.

Gupta, V. K., A. K. Misra and R. K. Gaur. 2010. Growth characteristics of Fusarium spp. causing wilt disease in Psidium guajava L. in India. J. Plant Protect. Res. 50: 452-461.

Hafizi, R., B. Salleh and Z. Latiffah. 2013. Morphological and molecular characterization of Fusarium solani and $F$. oxysporum associated with crown disease of oil palm Brazilian. J. Microbiol. 44: 959-968.

Hussain, M. Z., M. Rahman, M. N. Islam, M. Latif and M. Bashar. 2012. Morphological and molecular identification of Fusarium oxysporum sch. isolated from guava wilt in Bangladesh. Bangladesh J. Bot. 41: 49-54.

Islam, R. 2015. Effect of various carbon and nitrogen sources on mycelial growth of Fusarium spp. isolated from agricultural fields of Murshidabad. Indian J. Sci. Res. Technol. 3: 71-77.

Khilare, V. C. and R. Ahmed. 2011. Effect of nutritional sources on the growth of Fusarium oxysporum f. sp. ciceri causing chickpea wilt. Int. J. Sci. Nat. 2: 524-528.

Kuypers, W. 2001. Advanced Principal Components Analysis: A RealLife Application Using Statistica 6. Statsoft, INC., IBM, NED., Amsterdam.

Kumara, K. L. W. and R. D. Rawal. 2008. Influence of carbon, nitrogen, temperature and $\mathrm{pH}$ on the growth and sporulation of some Indian isolates of Colletotrichum gloeosporioides causing anthracnose disease of papaya (Carrica papaya L). Trop. Agric.
Res. Ext. 11: 7-12.

Lazarotto, M. 2013. Identificação e Caracterização de Fusarium spp. e Pestalotiopsis spp. Associados a Carya illinoinensis no Rio Grande Sul. Tese de doutorado. Universidade Federal de Santa Maria., Santa Maria.

Lazarotto, M., P. M. Milanesi, M. F. B. Muniz, L. R. S. Reiniger, R. Beltrame, R. Harakava and E. Blume. 2014. Morphological and molecular characterization of Fusarium spp. pathogenic to pecan tree in Brazil. Genet. Mol. Res. 13: 9390-9402.

Leslie, J. F. and B. A. Summerell. 2006. The Fusarium Laboratory Manual. $1^{\text {st }}$ ed. Blackwell Publishing., Ames, IA.

Leslie, J. F. and B. A. Summerell. 2011. In search of new Fusarium species. Plant Breed Seed Sci. 63: 93-101.

Lilly, V. G. and H. C. Barnett. 1951. Physiology of fungi. $1^{\text {st }}$ ed. McGraw-Hill., New York, U.S.

Menezes, M. and S. M. P. Assis. 2004. Guia prático para fungos fitopatogênicos. $2^{\text {nd }}$ ed. Imprensa Universitária., Recife, PE.

Nath, N., A. U. Ahmed and F. M. Aminuzzaman. 2017. Morphological and physiological variation of Fusarium oxysporum f. sp. ciceri isolates causing wilt disease in chickpea. Int. J. Environ. Agric. Biotechnol. 2: 202-212.

Shilpa, P., V. K. Rao, K. N. Rao, S. Girisham and S. M. Reddy. 2015. Influence of carbon and nitrogen source on growth, don and niv production by two species of Fusarium isolated from finger millets. Int. J. Pharm. Pharm. Sci. 7: 136-139.

Shinde, A. B. and B. V. Hallale. 2016. Effect of some physiological parameters on the growth of Fusarium oxysporum f. sp. Carthami. Int. J. Plant Sci. 11: 33-36.

Silva, F. A. Z. and C. A. V. Azevedo. 2002. Versão do programa computacional Assistat para o sistema operacional Windows. Rev. Bras. Prod. Agroindustr. 4: 71-78.

Somu, R., N. Thammaiah and G. S. K. Swamy. 2014. Effect of different carbon sources on the growth of different isolates of Fusarium oxysporum f. sp. cubense in different media. Int. J. Agric. Sci. Vet. Med. 2: 1-6.

Sousa M. V., J. C. Machado, L. H. Pfenning, V. H. Kawasaki, D. V. Araújo, A. A. Silva and A. M. Neto. 2008. Métodos de inoculação e efeitos de Fusarium oxyporum f. sp. vasinfectum in cotton seeds. Trop. Plant Pathol. 33: 41-48.

Tapia, C. and J. Amaro. 2014. Género Fusarium. Rev. Chilena Infectol. 31: 85-86.

Thaware, D. S., O. D. Kohire, V. M. Gholve, S. S. Wagh and A. Chavan. 2016. Nutritional and physiological studies of Fusarium oxysporum f. sp. ciceri (Padwick) Snyder and Hansen causing wilt of chickpea. Int. J. Plant Sci. 11: 213-217.

Yockteng, R., G. C. Eeckenbrugge and T. T. Souza-Chies. 2011. Passiflora. In: Kole, C. (Ed.), Wild Crop Relatives: Genomic and Breeding Resources. Springer., Berlin, GER, pp. 129-171.

Veras, S. M., L. Gasparotto and M. Menezes. 1997. Avaliação isoenzimática de Colletotrichum guaranicola. Arq. Biol. Tecnol. 40: $548-553$. 